\title{
Pre-College and In-College Experiences that Contribute to Women Selecting and Persisting through STEM and Arts Majors at an Undergraduate Institu- tion
}

\section{Capt. Allison Webster-Giddings, Vanderbilt University}

Allison Webster-Giddings is a Doctorate of Education candidate at Peabody College, Vanderbilt University in Higher Education Leadership and Policy. She served in the U.S. Navy as an experimental flight test pilot with extensive experience in the MH-60S/R Seahawk helicopter developmental programs. She served as the Department of Defense representative in Lockheed Martin, Owego, NY facility. She joined the faculty of the United States Naval Academy, Weapons and Systems Engineering Department in 2001. There, she has taught and developed engineering, design and leadership courses. She has received the Admiral Jay L. Johnson Professorship of Leadership and Ethics in 2015, and has served as Associate Chair, Weapons and Systems Engineering, and Director of Faculty and Staff Programs in the Stockade Center for Ethical Leadership.

\section{Ms. Nancy Dickson, Vanderbilt}

Nancy Dickson is currently the Program Director for the Hubert H. Humphrey Fellowship Program, a Fulbright exchange program for educational leaders from developing countries. Additionally, she trains and endorses high school teachers throughout the state in the area of service learning for the Tennessee Department of Education. Prior to working at Vanderbilt, she was the Director of Operations and a founding team member of LEAD Academy, a public charter school in Nashville. While teaching 4th grade in Washington, D.C. public schools, Nancy collaborated with National Geographic, Meridian International, and George Washington University to provide citywide professional development and teacher preparation programming. As an active member in the community, Nancy has served as the board chair of Nashville International Center of Empowerment (NICE) and All About Women as well as the co-chair for Alignment Nashville's Parent Engagement Team. She holds a Master of Public Policy degree from Vanderbilt and a Bachelor of Art degree in Elementary Education from Penn State University. Currently, Nancy is pursing a Doctorate of Education at Vanderbilt University's Peabody College in Higher Education Leadership and Policy.

\section{Dr. Melissa S Martiros, Anna Maria College}

Melissa Martiros currently serves as Assistant Professor and Director of Music at Anna Maria College. An active clinician, her recent engagements have included workshops across the United States, Canada, Europe, and Australia. She is a co-author of Inclusive Piano Teaching, a blog sponsored by the Frances Clark Center for Keyboard Pedagogy, and is co-chair of the committee on special needs for the National Conference on Keyboard Pedagogy. She is the Founding Director of OpporTUNEity Music Connections, a nationally recognized, award-winning engagement initiative for underserved youth and children with special needs.

Melissa is currently pursuing a Doctor of Education degree in Higher Education Leadership and Policy at Vanderbilt University where she is the recipient of the Deans Tuition Scholarship for Achievement. She earned a Doctor of Musical Arts degree in Piano Performance and Pedagogy and a Master of Science degree in Special Education from the University of Wisconsin Madison, a Master of Music degree in Piano Performance from Bowling Green State University, and a Bachelor of Arts degree in Piano Performance from Westfield State University, where she was the recipient of the Presidential Merit Scholarship and Excellence in Music Performance Award.

Ms. Sarah Mullen, Vanderbilt University 


\title{
Pre-College and In-College Experiences that Contribute to Women Selecting and Persisting through STEM and Arts Majors at an Undergraduate Institution
}

\begin{abstract}
Women are underrepresented in STEM fields at the college level and beyond. Existing research identifies pre-college and in-college factors that influence women to choose college majors in STEM fields. At the same time, trends in education have promoted the incorporation of Arts and Design, an area where women are comparatively overrepresented, into the STEM paradigm. Survey data were collected from students at a private, Midwestern university to explore the various pre-college and in-college experiences that have influenced students' major choices in fields across the STEAM spectrum. These experiences were categorized by organized inquiry, individual inquiry, adult mentoring, peer mentoring, and common design process as we compared and contrasted students in STEM and Arts disciplines. The results suggest that further study of the relationship between STEM and Arts may allow researchers, policymakers, and educators to better understand and address the gender gap that exists in STEM.
\end{abstract}

\section{Introduction}

Much research has focused on the factors that influence women to choose college majors in STEM (Science, Technology, Engineering, and Mathematics) fields (Grant, Battle, \& Heggoy, 2000; Rask, 2010; Sax \& Harper, 2007; Whitt, Pascarella, Nesheim, Marth, \& Pierson, 2003). This literature reveals a range of pre-college influences, from role models and societal expectations to extracurricular exposure and high school coursework. These factors are equally influential at the elementary, middle, and high school levels (Blackhurst et al., 2008) and continue through college (Cannes \& Rosen, 1995; Rask, 2010; Sax \& Harper, 2007). At the same time, women remain underrepresented in STEM fields (National Science Foundation, National Center for Science and Engineering Statistics, 2015). The National Science Foundation's biannual report, Women, Minorities, and Persons with Disabilities in Science \& Engineering (2015), found that women are underrepresented in engineering, computer sciences, mathematics, statistics, and physics majors. The National Center for Education Statistics reported significant gaps in its Digest of Education Statistics for 2015; while women earned 57\% of all bachelor's degrees, only $41 \%$ of those were in STEM majors. Without the women-dominated field of psychology (77\% women), STEM major representation drops to 35\%. In contrast, women are much more likely to choose majors in fields such as education $(79 \%)$, the arts $(61 \%)$, and the humanities (Olson, 2014).

In this study we explored the pre-college and in-college factors that contribute to male and female students' choice of and persistence through majors in STEM and the Arts. By focusing on the factors that contribute to the high levels of representation of women in the Arts (Olson, 2014), we hoped to better understand the factors that contribute to the underrepresentation of women in STEM fields. 


\section{Women in STEM: Pre-College and In-College Experiences}

Women are underrepresented in many STEM fields (NSF, 2017), especially computer and information sciences (18\%) and engineering and engineering technologies (18\%). According to Speer (2007), the gender gap in the sciences begins prior to the age of fourteen. This gender gap therefore begins to formulate well before college, perhaps as early as elementary and middle school, when children begin to develop career aspirations (Blackhurst et al., 2009). Sax \& Harper (2007) suggest that "the source of gender differences extends back into the pre-college years, when women and men develop different values, confidences, aspirations, and patterns of behavior" (Sax \& Harper, 2007, 690). In order to understand the gender gap in STEM fields, it is important to understand the factors contributing to college major selection that begin to develop well before college enrollment. A large body of research has focused on the pre-college factors and experiences that influence this gender gap in STEM. The majority of these influences fall within three main categories: academic and nonacademic experiences (Goldin et al, 2006; Grant et al, 2000; Whitt et. al, 2003), adult role models and mentoring (Cannes \& Rosen, 1995; Grant et al., 2000; Speer, 2017) and peer relationships (Dick \& Rallis, 1991; Miller \& Kimmel, 2012; Speer, 2017). Furthermore, academic and nonacademic experiences can be described as inquiry based (organized and independent) activities which allow students to "formulate their own problems to investigate" (Mergendoller, Maxwell, \& Bellisimo, 2006, p.62), and can be a "predictor of future success" (Colburn, 2000, 42). The presence of female role models in the sciences, particularly female teachers, can play a positive role in inspiring women to select STEM majors in college (Hackett, 1989; Cannes \& Rosen, 1995; Dick \& Rallis, 1991). Other pre-college influences include socialization in school, social media engagement, and other peerrelated experiences in high school (Miller \& Kimmel, 2012).

Extensive literature explores the in-college experiences that lead women to persist through undergraduate majors in STEM. Similar to pre-college experiences, these factors range from academic and nonacademic experiences to faculty mentorship and peer relationships (Cannes \& Rosen, 1995; Sax \& Harper, 2007; Moss-Racusin et al, 2012). Rask (2010) found that the grades received, gender of the instructor, and peer factors equally influence female students' decisions to persist through STEM majors in college. Moss \& Racusin (2012) found that subtle faculty biases contribute to the gender gap in STEM, as male and female faculty members judged female students to be less competent and worthy of being hired than identical male students. In contrast, Sax \& Harper (2007) discovered that the gender of the instructor can positively influence female undergraduate students' persistence through STEM majors. Female faculty members in STEM provide mentorship and support that can inspire undergraduate female students to persist. Moreover, women who feel supported by faculty have higher rates of degree attainment and earn higher grades (Sax \& Harper, 2007). Undergraduate women in STEM majors experience lower levels of confidence and higher levels of performance pressure and stress than their male peers (Rogers, 1991; Sax \& Harper, 2007). However, this pressure often drives women to be successful in their prospective majors and to do well academically (Sax \& Harper, 2006). 


\section{STEM \& Arts: The Transition to STEAM}

The existing research explores key factors that encourage or discourage women to declare and persist in STEM majors. However, even as more women are attending college than are men, the gender gap in STEM remains (NSF, 2015). Indeed, "substantial decrease in the ratio of maleto-female undergraduates is apparent for all types of institutions including research universities, liberal arts colleges, public institutions, and private institutions; for both full-time and part-time enrollment; and for all ethnic and racial subgroups" (Goldin et al, 2006, 7). As the US economy demands further growth and innovation, Arts and Design majors are seen as a necessary and integral element for such change (Bequette \& Bequette, 2012). Consequently, there has been a push, especially in K-12 education, to add "A" (Art \& Design), transforming STEM into STEAM (Bequette \& Bequette, 2012, Piro, 2010; White, 2011). Although, there seems to be a sympathetic relationship between Art and STEM majors, there is limited research identifying the key experiences or factors that foster the relationship between STEM and Arts which is evident in the number and types of degrees conferred by women (Piro, 2010) (see Figure 1: Degrees Conferred by Women).

By "examining how artists mix art, science, technology, and math in imaginative artworks that blur boundaries between art, design, and STEM disciplines" (Bequette \& Bequette, 2012, p.43), those in all fields can better understand the value of the intellectual skills and mind sets developed through the arts (Hetland, Winner, Veenema, \& Sheridan, 2007). Stanford's Design School is a leader in design and problem solving because it has found a way to merge Arts and STEM. The d.school is guided by eight core abilities which provide the platform for innovation and creativity across and within fields - STEM, the Arts, and many of the other majors on Stanford's campus (Stanford - the d.school, 2017). ${ }^{1}$ STEAM is thus incorporated into the d.school to solve real world problems and challenges. The d.school's STEAM focus has inspired our study, which compared and contrasted STEM and Arts majors in an attempt to better understand the selection of STEM and Arts majors' pre-college and in-college experiences in order to guide more women into STEM.

\section{Conceptual Framework}

The research reported here is the result of a quantitative study designed to examine the factors that contribute to men and women selecting and persisting through majors in STEM and Arts disciplines at an undergraduate institution in the Midwest. Specifically, we studied the precollege experiences and in-college experiences that influence female and male undergraduate students' decisions to declare and persist through these majors. Arts disciplines recruit women more successfully than do traditional STEM fields as evidenced by the higher percentage of women who received Bachelor's degrees in Arts related fields in 2014 (Olson, 2014). We

\footnotetext{
${ }^{1}$ The eight core abilities are: navigate ambiguity, learn from others, synthesize information, experiment rapidly, move between concrete and abstract, build and craft intentionally, communicate deliberately, and design your design work.
} 
hypothesized that there are commonalities among and differences between students' pre-college and in-college experiences that contribute to their selection of Arts and STEM majors. By using male students' experiences as a point of comparison, we hoped to gain a better understanding of how female students' experiences may or may not differ.

One of our primary goals was to compare pre-college and in-college experiences of Arts majors and STEM majors. By identifying any commonalities among the disciplines and comparing the different experiences of male and female students, we hoped to better understand which experiences contribute to woman's selection and persistence in STEM and Arts majors. We set out to answer the following questions: What are the pre-college and in-college experiences that influence students' selection of and persistence through majors in STEM and the Arts? What are the differences between female and male students' experiences among those who major in STEM and those who major in the Arts? To answer these questions, we administered a survey and ran a series of statistical analyses in order to better understand the relationships between pre-college and in-college experiences, STEM and Arts' majors, and gender. In so doing, we hope to inform policies and programs that seek to address the gender gap that exists in STEM majors and professions.

\section{Data}

\section{Sampling Instrument}

We created a survey to support the investigation of the research questions. Survey questions were drawn from three sources: Harvard-Smithsonian Center for Astrophysics Outreach Programs and Science Career Intentions (OPSCI) Survey of Students in Introductory College Classes (OPSCI, 2013), the 2017 National Survey of Student Engagement (NSSE, 2017), and the Survey Instruments for the Engineer of 2020 Study (Lattucca \& Terenzini, 2004) and sixty-nine of the questions were developed by the research team (Figure 2: Survey Questions Source). The research team structured the questions around the themes that arose from the existing research on STEM and the Arts, organizing them into five scales - organized inquiry, individual inquiry, adult mentoring, peer mentoring, and common design process experiences in Arts and STEM disciplines. To track the alignment of the survey with the research questions, we mapped each survey question to our research question (Figure 3: Concept Map).

\section{Material, Sampling Procedures, \& Participants}

We distributed the survey during a 30-day period to all freshman, sophomore, junior, and senior students at a mid-sized, four-year, religiously-affiliated private institution in the Midwest. Two reminder emails were sent in order to ensure a higher response rate. Our combined target population was approximately 1,609 undergraduate students with a gender breakdown of 53\% women and $47 \%$ men in a broad range of undergraduate majors. 110 responses were received, including 59 STEM majors, 17 arts majors and 23 students who identified as having a major in neither of those categories. The overall response rate was $9.4 \%$. Due to the limited scope of this project and the barriers to human subject access, the feasibility of our sample leaves our study 
subject to sampling bias, making it difficult to generalize our results beyond the institution sampled for this project.

\section{Variables}

This study included four dependent variables representing student interest in STEM and Arts majors pre-college and during college. Participants were afforded the opportunity to indicate interest in multiple majors - these were coded accordingly. A complete list of the majors used for each variable is included in Table 1. Five independent types of experiences are central to the theory provided in the previous sections. These are peer mentoring, adult mentoring, organized inquiry, independent inquiry, and design process experiences. Ten scales were used as outcome measures for this study. Two scales represent each of the five experience types: One for before-college experiences (before-college-experience), and one for in-college experiences (during-college-experience). Each of these two scales included the same experiences, differentiated only by the time period when students experienced them. A complete list of the questions that comprised the scales and their reliabilities are shown in the Appendix A. Our analysis utilized gender as a moderating variable, as it is a key component of our research question and three control variables: race, high school grades, and mother's education level. A Table 2 summarizes the variable types. Table 3 provides the individual characteristics of our research participants.

\section{Methods}

Once the data were collected, we ran a variety of statistical analyses in order to provide further insight into our research questions. First, since the majority of the variables was categorical, we used the chi squared test of independence to determine the distribution of frequencies when examining the relationship between a given experience and students' major selections. For example, chi squared tests were calculated comparing the frequency of students' intended major and whether or not they had a particular type of pre-college experience. Similarly, we compared the frequency of students' actual majors with both their pre-college experiences and their in-college experiences.

Second, we ran linear regressions on the binary-coded independent variables to determine which pre-college experiences influence major selection and which in-college experiences are associated with major persistence for STEM or Arts majors. In running these regressions, we chose to separate the inquiry-based experiences in STEM and the arts (both independent and organized). This allowed us to understand the various relationships between different kinds of experiences and students' intended and actual college majors. We held pre-college experiences constant when examining in-college experiences. Additionally, we controlled for our moderating variable (gender) and control variables ( race, level of mother's education/SES and high school grades). Table 4 provides the regression results for four of the experience types that this study measured (peer mentoring, adult mentoring, organized inquiry, and independent inquiry).

Third, to determine whether students saw pre-college or in-college experiences as more influential in their choice of major, we used a paired t-test to compare the means of each type of 
pre-college and in-college experience, utilizing students' responses to the Likert scale questions. (Table 5).

Finally, we ran twelve regressions on the data provided by students' responses to our Likert scale questions regarding their perceived influence of each type of independent variable on their college major (Table 6). The survey asked participants to rank (None, A little, A moderate amount, A lot, A great deal) the influence of four types of experiences (peer mentoring, adult mentoring, organized inquiry, independent inquiry) before and during college on their selection of a college major. As with the non-Likert regression, we controlled for both our moderating and control variables and ran a regression accounting for all four experience types,

\section{Results}

\section{Chi Squared Tests}

Our analysis found that a number of relationships were statistically significant at conventional levels, reflecting some of the findings in the existing literature, and providing new avenues for exploration that the literature has not yet addressed.

First, as we explored various inquiry-based experiences for STEM majors, we found that students who had an influential pre-college independent inquiry experience in STEM were more likely to have an intended major in STEM (84\%) than those who had a non-influential independent inquiry STEM experience (69\%). These two findings suggest that simply having pre-college independent inquiry experiences influence students' choice of major, whether they consider the experience 'influential' or not. This finding suggests that in-college independent inquiry experiences can influence students' persistence in STEM majors.

When we explored organized inquiry experiences for STEM majors, we found that students who had an influential pre-college organized inquiry experience in STEM were more likely to have an intended major in STEM (88\%) than those who had a non-influential organized inquiry STEM experience (75\%). Similarly, to the independent inquiry experiences, this finding suggests that in-college organized inquiry experiences may be related to students' persistence in STEM majors, although it is also possible that these experiences arose out of students' major choices, and not the other way around.

When exploring inquiry-based experiences for students in the arts, we found that students who had influential pre-college independent inquiry experiences in the arts were more likely to declare a major in the arts $(27 \%)$ than those who did not $(0 \%$ for those who had non-influential independent inquiry experiences, $13 \%$ for those who had no independent inquiry experiences at all) $\left(\chi^{2}=10.111, \mathrm{p}<.01\right)$. This suggests that, for students in the arts, the quality of the independent inquiry experience matters more than whether or not the student had the experience at all. Similarly, students who had influential pre-college organized inquiry experiences in the arts were more likely to have an intended major in the arts (54\%) than those who did not (4\% for those who had a non-influential organized inquiry experience, $15 \%$ for those who had no organized 
inquiry experiences at all $)\left(\chi^{2}=21.65, \mathrm{p}<.001\right)$. As with the findings regarding independent inquiry, these findings suggest that the quality of the experience matters more than the experience itself.

The above findings largely reflected those of the existing literature. However, when it came to inquiry-based experiences in the arts, we found that there was a relationship between students' experiences in the arts and their intended and actual majors in STEM. When it came to intended majors, students who had an influential pre-college independent inquiry experience in arts were about as likely to have an intended major in STEM (82\%) as those who had a noninfluential pre-college independent inquiry arts experience (83\%). Both of these groups were significantly more likely to have an intended major in STEM than those who had no pre-college independent inquiry arts experience at all $(46 \%)\left(\chi^{2} 15.37, \mathrm{p}<.001\right)$. This suggests that having pre-college independent inquiry arts experiences may be related to students' intended majors in STEM fields, regardless of the quality of that experience.

On the other hand, students who had an influential pre-college independent inquiry experience in arts were less likely to actually major in STEM (57\%) than those who had a noninfluential independent inquiry arts experience (69\%). Both of these groups were more likely to major in STEM than students who had no pre-college independent inquiry arts experience at all $(38 \%)\left(\chi^{2}=6.63, \mathrm{p}<.05\right)$. Similarly, students who had an influential in-college independent inquiry experience in arts were less likely to actually major in STEM (56\%) than those who had a non-influential independent inquiry arts experience (77\%). Yet both of these groups were more likely to major in STEM than students who had no in-college independent inquiry arts experience at all $(42 \%)\left(\chi^{2}=8.74, \mathrm{p}<.05\right)$. This finding was also reflected in the test for precollege organized inquiry experiences, although the result was not significant at conventional levels. Students who had non-influential pre-college organized inquiry experience in arts were more likely to actually major in STEM $(75 \%)$ than either those who had an-influential organized inquiry arts experience $(50 \%)$ or those who had no pre-college organized inquiry arts experience at all $(47 \%)\left(\chi^{2}=5.71, \mathrm{p}<.10\right)$. These findings suggest that having certain pre- or in-college inquiry-based experience in the arts can positively influence a student's choice of and persistence in a STEM major. At the same time, it suggests that merely having the experience, regardless of quality, may be most important for students majoring in STEM.

When examining the relationship between adult mentoring and STEM major choice and persistence, we found that students who had some kind of pre-college adult mentoring experience before college were more likely to have an intended major in STEM (83\% for those with influential mentoring experiences, $73 \%$ for those with non-influential mentoring experiences) than those who did not $(50 \%)\left(\chi^{2}=13.53, \mathrm{p}<.01\right)$. Students who had some kind of influential adult mentoring experience before college were also more likely to actually major in STEM (68\%) than those who had a non-influential adult mentoring experience $(45 \%)$. Both of these groups were more likely to major in STEM than students who had no pre-college adult mentoring experiences at all $(33 \%)\left(\chi^{2} 11.97, \mathrm{p}<.01\right)$. These findings suggest that having a precollege adult mentoring experience at all matters more than the quality of the experience. Conversely, we found that students who had some kind of influential in-college adult mentoring 
experience were more likely to major in stem $(70 \%)$ than those who did not (33\% of those who had a non-influential adult mentoring experience, $38 \%$ of those who had no adult mentoring experience at all $)\left(\chi^{2}=11.84, \mathrm{p}<.01\right)$. This suggests that once students get to college, the quality of the mentorship matters more for persistence than merely having the experience itself.

When examining the relationship between peer mentoring and STEM major choice and persistence, we found that students who had some kind of in-college peer mentoring experience were more likely to have an intended major in STEM (80\% for those with influential peer mentoring experiences, $81 \%$ for those with non-influential peer mentoring experiences) than those who did not $(49 \%)\left(\chi^{2}=11.24, \mathrm{p}<.01\right)$. Similarly, students who had some kind of precollege peer mentoring experience were more likely to actually major in STEM (61\% for those with influential peer mentoring experiences, $62 \%$ for those with non-influential peer mentoring experiences) than those who did not (37\%), although this result was not statistically significant at conventional levels $\left(\chi^{2}=5.62, \mathrm{p}<.10\right)$. These findings support the argument that mentoring matters for students in STEM that many others have mentioned. Pre-college peer and adult mentoring experiences can be seen as crucial to students' eventual choice of major, while incollege mentoring experiences likely influence students' persistence in their field of choice. Conversely, the relationship between both peer and adult mentoring was not statistically significant in relation to students' intended or actual majors in the arts.

\section{Regression on Independent Variables}

The first regression examines the relationship between an intended major in STEM and our pre-college independent variables, gender (our moderating variable), and our control variables (race, high school grades, and SES). No relationship was found between any of these variables and students' intended major in STEM. The second regression examines the relationship between a student's declared STEM major and the variables listed above. Holding all other variables constant, the regression showed a positive relationship between pre-college adult mentoring experiences and a declared major in STEM, significant at conventional levels $(\mathrm{p}<.05)$.

The third regression examines the relationship between a student's declared STEM major and both pre-college and in-college independent variables, in addition to the moderating and control variables listed above. In interpreting these results, we have chosen to disregard the students' pre-college experiences, largely because it did not make logical sense to hold current experiences constant when considering past experiences (as the future cannot influence the past). However, since past events can influence future events, holding all variables constant, we sought to understand how in-college experiences might be related to a students' declared STEM major. Among these, we found a moderately positive relationship (+.314) between in-college adult mentoring experiences and a student's persistence in STEM; while we found a moderately negative (-.370) relationship between in-college peer mentoring experiences and persistence in STEM, both statistically significant at conventional levels $(\mathrm{p}<.05)$. 
The fourth regression examines the relationship between a student's intended major in the arts and our pre-college independent variables, gender, and our control variables. Holding all variables constant, we found that a pre-college organized inquiry experience in the arts had a highly positive influence on a student's intended major in the arts $(+.518, \mathrm{p}<.001)$. We also found that female students were somewhat less likely than male students to have an intended major in the arts $(-.202, \mathrm{p}<.05)$. The fifth regression examines the relationship between a student's declared arts major and the variables listed above. Holding all other variables constant, we found that a pre-college independent inquiry experience in the arts had a somewhat positive influence on students' choice of an arts major $(+.278, \mathrm{p}<.001)$. In addition, a pre-college organized inquiry experience in the arts had a somewhat positive influence on students' choice to major in the arts $(+.267, \mathrm{p}<.05)$.

The sixth regression examines the relationship between a student's declared arts major and his or her in-college experiences, holding all other variables (pre-college experiences, moderating, and control) constant. The results showed that an in-college organized inquiry experience had a moderate positive relationship with a student's persistence in the arts $(+.442$, $\mathrm{p}<.01)$. However, this is not necessarily a causal relationship; it is likely that participation in arts activities is a required component of many arts majors.

Overall, these findings largely reflect both the literature and our other findings, which suggest that mentoring matters most in STEM, and less so in the Arts. On the other hand, independent and organized inquiry experiences matter much more for the choice of and persistence through a major in the Arts. At the same time, the negative association between being female and an intended arts major may reflect a trend that contradicts the data reported in existing literature regarding the greater numbers of women in the arts. However, this may only reflect the qualities of this particular student sample, so should not be generalized to the population at large.

\section{Paired Samples T-Test}

There was no measurable difference in how students perceived the influence of their precollege and in-college independent or organized inquiry experiences. These results suggest that there is no measurable difference in the influence of independent inquiry and organized inquiry experiences on students' major selection based on when students had the experience. However, it is possible that organized inquiry experiences have a slightly greater influence on students when they occur during college.

On the other hand, there was a significant difference in how students perceived the influence of their pre-college $(\mathrm{M}=2.653, \mathrm{SD}=1.219)$ and in-college $(\mathrm{M}=3.010, \mathrm{SD}=1.335)$ adult mentoring experiences; $t(97)=-2.651, p=0.0094$. There was also a significant difference in how students perceived the influence of their pre-college $(\mathrm{M}=3.020, \mathrm{SD}=1.292)$ and in-college $(\mathrm{M}=3.316, \mathrm{SD}=1.476)$ peer mentoring experiences; $\mathrm{t}(97)=-2.059, \mathrm{p}=0.0422$. These results suggest that in-college peer and adult mentoring experiences have a greater influence on students' major than do pre-colleges experiences of the same type. 


\section{Regression on Perceived Influence of Independent Variables}

Overall, regression on our Likert scale data did not indicate significant relationships between students' perceived influence of each of our independent variables and students' major choice or persistence. However, it is possible that different results would be found if the survey questions had been worded differently; they were relatively general and did not allow for disaggregation between the perceived influence of arts and STEM experiences.

\section{Conclusion}

College major selection has broad implications for individual quality of life, financial stability, career growth, and future potential. In an age where the relevancy and applicability of majors in STEM are rapidly increasing, it is troubling that the underrepresentation of women in STEM related fields continues to be prevalent. "Gender differences in major choices are extremely complex, and no simple explanation can be provided for them" (Zafar, 2009, 30). As part of the rationale for this study, we presented a large body of research that focused on the precollege and in-college experiences that contribute to the gender gap in STEM. While many studies have attempted to answer questions related to the nature of this gap, very few (if any) have examined the factors that influence a student's decision to select and persist through the Arts while simultaneously examining the factors that influence a student's decision to select and persist through STEM. The analysis presented in this paper contributes to our current understanding of the gender gap in STEM offering a comparison of the similarities and differences between STEM and the Arts in order better understand the gender disparities in STEM fields.

By exploring research questions related to the pre-college and in-college experiences that influence students' selection of and persistence through majors in STEM and the Arts as well as the differences between female and male students' experiences among those who major in STEM and those who major in the Arts, we hoped broaden the literature related to the relationship between gender and both STEM and STEAM. As we designed our quantitative study, we expected to see an underrepresentation of women in STEM and an overrepresentation of women in Arts. However, this was not represented in the data collected for our sample as our study revealed that women are less likely to go into the arts. However, this contradictory finding can easily be traced back to the limitations of our study and should be interpreted with absolute caution.

The results of this study shed light on important experiences that influence undergraduate students' selection of and persistence through a STEAM related major. Unsurprisingly, respondents indicated that they had been influenced by parents, relatives, teachers and counselors. While we expected to see the strong influence of adult mentoring experiences, the results of our study revealed a noteworthy twist in that our participants distinguished between the 
quality of this mentorship and its influence on major choice and persistence. We recommend that more research be done in order to further examine the relevancy of this finding.

Perhaps most significant is the relationship between the influence of pre-college factors for STEM and the Arts. Specifically, having certain pre- or in-college inquiry-based experiences in the arts can positively influence a student's choice of and persistence in a STEM major, regardless of gender. Our data suggest that merely having the experience, regardless of quality, may be most influential upon students' choices to major in STEM. The results of this study, despite a small sample size and low survey response rate, give rise to questions surrounding conventional assumptions regarding the quality of the experience, and we recommend that future research be conducted in order to further examine the significance of this finding.

As with most research studies, our data have limitations that make it impossible to generalize our results to the broader student population in the United States. While the limitations of our project undoubtedly influenced our results, we feel confident that the results presented in our study are worthy of further consideration. Further research is needed to broaden the scope of our findings. However, since we did find a significant relationship between the influence of arts-related experiences on the selection of STEM majors, it would benefit all STEAM-related fields to continue exploring the relationship between STEM and the Arts. We recommend that, in the future, researchers, educators, and policymakers continue to explore this relationship in order to better understand the gender gap that exists in all STEM-related fields. 


\section{References}

Beede, D., Julian, T., Langdon, D., McKittrick, G., Khan, B., \& Doms, M. (2011). Women in STEM: A Gender Gap to Innovation. ESA Issue Brief \#04-11. Washington D.C.: US Department of Commerce: Economics and Statistics Administration.

Bequette, J., \& Bequette, M. (2012). A Place for art and design education in the STEM conversation. Art Education, 65(2), 40-47.

Blackhurst, A. E., \& Auger, R. W. (2008). Precursors to the Gender Gap in College Enrollment: Children's Aspirations and Expectations for the Futures. Professional School Counseling: February 2008, Vol. 11, No. 3, 149-158.

Buchmann, C., DiPrete, T. A. (2006) The Growing Female Advantage in College Completion: The Role of Family Background and Academic Achievement. American Sociological Review: August 2006, Vol. 71, No. 4, 515-541.

Canes, B. J., Rosen, H. S. Following in Her Footsteps? Faculty Gender Composition and Women's Choices of College Majors. Industrial and Labor Relations Review: April 1995, Vol. 49, No. 3.

Charles, M., Bradley, K. Equal but Separate? A Cross-National Study of Sex Segregation in Higher Education. American Sociological Review: August 2002, Vol. 67, No. 4, 573-599.

Cheryan, S., Ziegler, S., Montoya, A., \& Jiang, L. (2017). Why Are Some STEM Fields More Gender Balanced Than Others? Psychological Bulletin, 143(1), 1-35

Colburn, Alan. (2000). An Inquiry Primer. Science Scope, 23(6), 42-44.

Dick, T. P., \& Rallis, S. Factors and Influences on High School Students' Career Choices. Journal for Research in Mathematics Education: July 1992, Vol. 22, No. 4, 281-292.

Godwin, A., Potvin, G., Hazari, Z. and Lock, R. (2016), Identity, Critical Agency, and Engineering: An Affective Model for Predicting Engineering as a Career Choice. The Research Journal for Engineering Education. 105(2): 312-340.

Goldin, C., Katz, L. F., Kuziemko, I. The Homecoming of American College Women: The Reversal of the College Gender Gap. The Journal of Economic Perspectives: Fall 2006, Vol. 20, No. 4, 133-156. 
Goyette, K. A., Mullen, A.L. Who Studies Arts and Sciences? Social Background and the Choice of Consequent Undergraduate Field of Study. The Journal of Higher Education: MayJune 2006, Vol. 77, No. 3, 497-538.

Grant, D. F., Battle, D. A., \& Heggoy, S. J. (2000). The Journey through College of Seven Gifted Females: Influences on the Career Related Decisions. Roeper Review, 22:4, 251-260.

Hackett, G. The Relationship of Role Model Influences to the Career Salience and Educational and Career Plans of College Women. Journal of Vocational Behavior: 1989, Vol. 35, 164-180.

Hetland, L., Winner, E., Veenema, S., \& Sheridan, K. (2007). Studio thinking: The real benefits of arts education Teachers College Press. NY.

Lattuca, L., Terenzini, P. (2014). Survey Instruments for the Engineer of 2020 Study (Prototype to Production: Conditions and Processes for Educating the Engineer of 2020, NSF-EEC0550608).

Legewie, J., DiPrete, T. A. The High School Environment and the Gender Gap in Science and Engineering. Sociology of Education 201: 2014, Vol. 87, No. 4, 259-280.

Lent, Robert W., Brown, Steven D., Sheu, H., Schmidt, J., Brenner, B.R., Gloster, C.S., \& Lyons, H. (2005). Social Cognitive Predictors of Academic Interests and Goals in Engineering: Utility for Women and Students at Historically Black Universities. Journal of Counseling Psychology, 52(1), 84-92.

Lent, R. W., Brown, S. D., Schmidt, J., Brenner, B., Lyons, H., \& Treistman, D. (2003). Relation of contextual supports and barriers to choice behavior in engineering majors: Test of alternative social cognitive models. Journal of Counseling Psychology, 50(4), 458-465. Retrieved from http://login.proxy.library.vanderbilt.edu/login?url=http://search.proquest.com/docview/61 4443947? accountid=14816

Madden, M. E., Baxter, M., Beauchamp, H., Bouchard, K., Habermas, D., Huff, M., ... Plague, G. (2013). Rethinking STEM Education: An Interdisciplinary STEAM Curriculum. Procedia Computer Science, Volume 20, 541-546.

Mergendoller, J. R. , Maxwell, N. L. , \& Bellisimo, Y. (2006). The Effectiveness of ProblemBased Instruction: A Comparative Study of Instructional Methods and Student Characteristics. Interdisciplinary Journal of Problem-Based Learning, 1(2). Available at: $\underline{\text { htps://dx.doi.org/10.7771/1541-5015.1026 }}$

Moss-Racusin, C. A., Dovidio, J. F., Brescoll, V. L., Graham, M. J., Handelsman, J. Science Faculty's Subtle Gender Biases Favor Male Students. Proceedings from the National 
Academy of Sciences in the United States of America: October 2012, Vol. 109, No. 41, 16474-16479.

Miller, J. D., Kimmel, L. G. Pathways to a STEMM Profession. Peabody Journal of Education: 2012, Vol. 87, 26-45.

National Science Foundation, National Center for Science and Engineering Statistics. (2015). Women, Minorities, and Persons with Disabilities in Science and Engineering: 2015. Special Report NSF 15-311. Arlington: National Science Foundation.

National Science Foundation 2013. Higher Education Research Institute, University of California, Los Angeles, special tabulations (2015) of The American Freshman: National Norms; National Center for Education Statistics, Integrated Postsecondary Education Data System, Completions Survey, 2013; National Science Foundation, National Center for Science and Engineering Statistics, WebCASPAR database, http://webcaspar.nsf.gov.

National Science Foundation, Arlington, VA. Women, Minorities, and Persons with Disabilities in Science and Engineering: 2017.

Piro, J. (2010). Going from STEM to STEAM: The Arts have a role in America's future, too. Education Week. 29(24): 28-29.

Olson, R. S. (2014). Percentage of Bachelor's degrees conferred to women, by major (19702012). Retrieved March 2, 2017 at Randal S. Olson:

http://www.randalolson.com/2014/06/14/percentage-of-bachelors-degrees-conferred-towomen-by-major-1970-2012/.

Rask, K. (2010). Attrition in STEM fields at a liberal arts college: The importance of grades and pre-collegiate preferences. Economics of Education Review., Volume 29, Issue 6, 892900.

Rogers, S. J. Women's Persistence in Undergraduate Majors: The Effects of GenderDisproportionate Representation. Gender and Society: December 1991, Vol. 5, No. 4, pp. 549-564.

Sadler, P., Sonnert, G. The OPSCI questionnaire was developed at the Science Education Department at the Harvard College Observatory under a research grant from the National Science Foundation (\#1161052)." Outreach Programs and Science Career Intentions (OPSCI).

Sax, L. J., \& Harper, C. E. (2007). Origins of the Gender Gap: Pre-College and College Influences on Differences Between Men and Women. Research in Higher Education, September 2007, Volume 48, Issue 6, 669-694. 
Speer, Jamin. D. The Gender Gap in College Major: Revisiting the Role of Pre-College Factors. Labour Economics: 2017, Vol. 44, 69-88.

Stanford -the d.school. (2017). 8 Core abilities. Retrieved from https://dschool.stanford.edu/about/

White, H. (2011). STEM to STEAM: The future of American innovation. Retrieved March 2017 from http:// steam-notstem.com/articles/ whitepaper/

Whitt, E. J., Pascarella, E. T., Nesheim, B. E., Marth, B. P., \& Pierson, C. T. Differences Between Women and Men in Objectively Measured Outcomes, and the Factors That Influence Those Outcomes, in the First Three Years of College. Journal of College Student Development: September/October 2003, Vol. 44, No. 5, 587-610.

Whitt, E. J., Pascarella, E. T., Nesheim, B. E., Marth, B. P., \& Pierson, C. T. (2003). Differences Between Women and Men in Objectively Measured Outcomes, and the Factors That Influence Those Outcomes, in the First Three Years of College. Journal of College Student Development, Volume 44, Number 5, September/October 2003, 587-610. 


\section{FIGURES}

Figure 1

Degrees Conferred by Women

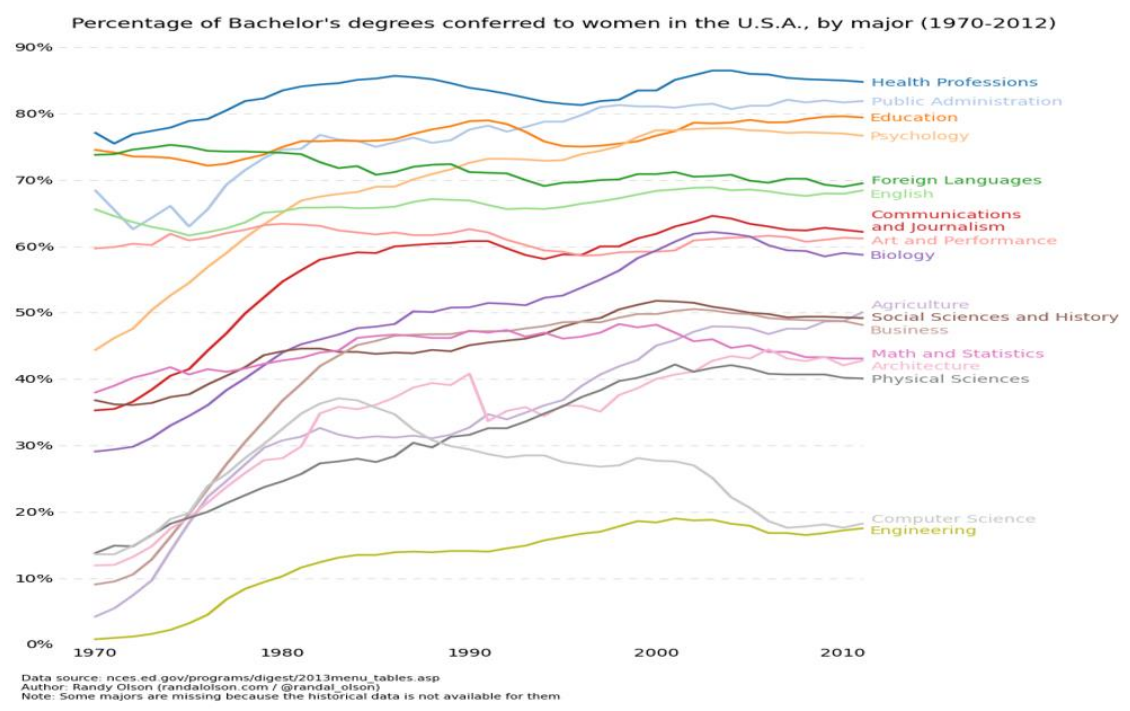

Figure 2

Survey Questions Source

\begin{tabular}{lll}
\hline Question Numbers & Source & Questions per source \\
\hline Q 12.4; Q15.1; Q15.8; Q15.9 & Lattuca & 4 \\
Q 11.9; Q11.15; Q11.6; Q12.1 & Means, Wang, Young and Peters, 2016 & 4 \\
Q15.7 & NSSE 2017 & 1 \\
Q 11 - Q11.8; Q11.10- Q11.13 & OPSCI & 13 \\
Q 13 - Q13.6 & SDS & 7 \\
Q3-Q9; Q9.1-Q9.4; Q10-Q10.4; Q11.14; & Research team derived $\quad$ Total \# of Questions= & 98 \\
& \multicolumn{2}{r}{}
\end{tabular}


Figure 3

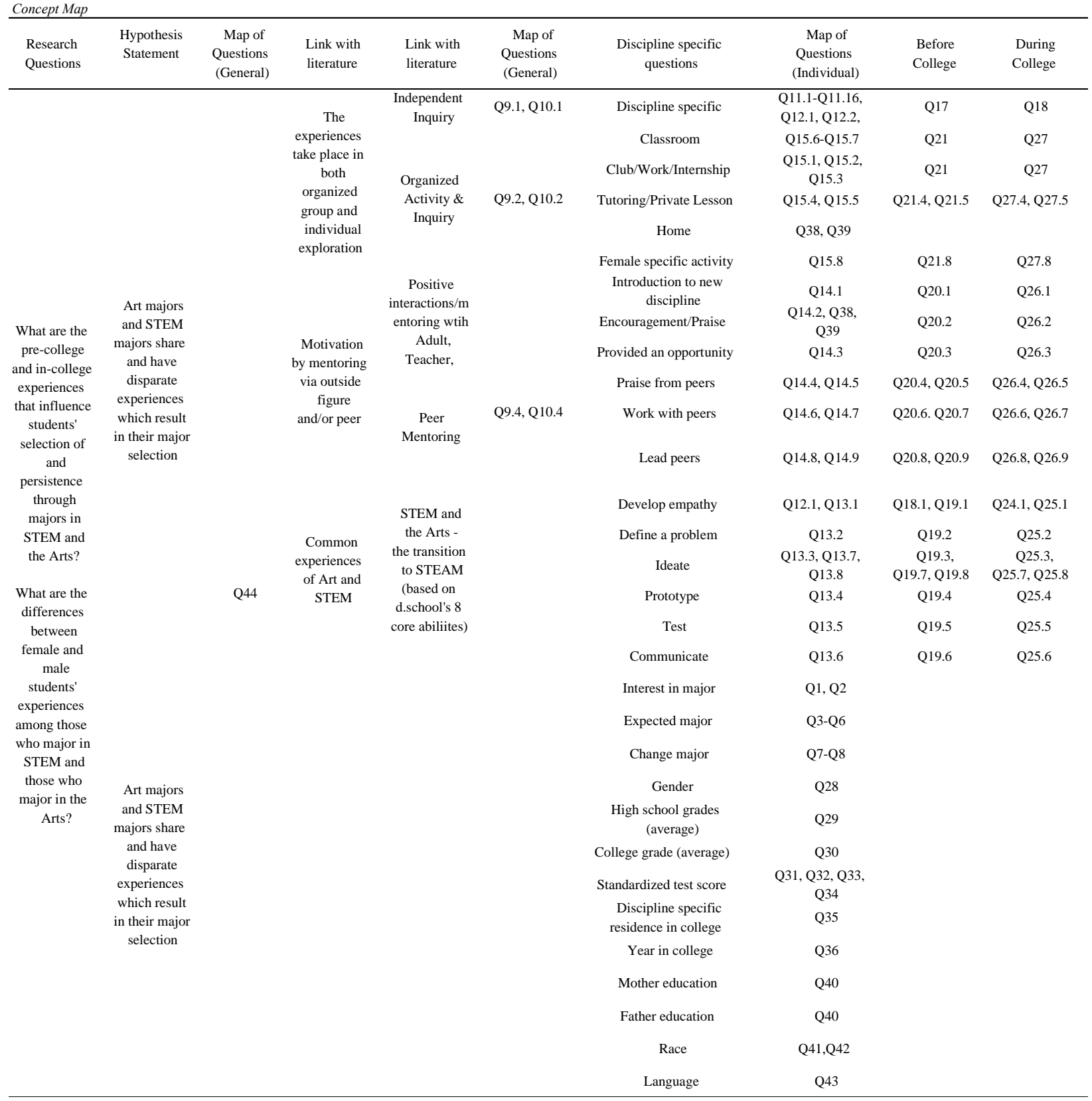




\section{TABLES}

Table 1

List of interest in STEM and arts majors

\begin{tabular}{lcc}
\hline & $\begin{array}{c}\text { Before } \\
\text { College } \\
(\mathrm{n}=110)\end{array}$ & $\begin{array}{c}\text { During } \\
\text { College } \\
(\mathrm{n}=110)\end{array}$ \\
\hline STEM majors & 77 & 59 \\
Accounting, Aeronautical/Astronautical Engineering, Biology, & \\
Chemistry, Computer Engineering, Computer Networking, & \\
Computer Science, Economics, Electrical Engineering, & \\
Environmental Science, Exercise Science, Health Science, Marine & \\
Biology, Mathematics, Mechanical Engineering, Naval & \\
Architecture Engineering, Nuclear Engineering, Nursing, Ocean & \\
Engineering, Operations Research, Physics, Pre-me, Psychology, & \\
Systems Engineering, Cyber Systems & \\
Arts majors & 23 & \\
Music, Performing Arts, Theater, Visual Arts & & \\
Other majors & 10 & 34 \\
\hline
\end{tabular}

Table 2

Summary of variable types

\begin{tabular}{|c|c|c|c|c|}
\hline Dependent & Independent & Moderating & Control & Intervening \\
\hline Variables & Variables & Variables & Variables & Variables \\
\hline \multirow{2}{*}{$\begin{array}{l}\text { Selection and } \\
\text { persistence in a } \\
\text { STEM or Arts } \\
\text { major }\end{array}$} & $\begin{array}{l}\text { Before-college } \\
\text { experiences }\end{array}$ & \multirow{2}{*}{ Gender } & \multirow{2}{*}{$\begin{array}{l}\text { Demographic } \\
\text { information: } \\
\text { gender, race, } \\
\text { high school } \\
\text { grades, mother's } \\
\text { education }\end{array}$} & \\
\hline & $\begin{array}{l}\text { During-college } \\
\text { experiences }\end{array}$ & & & Expected major \\
\hline
\end{tabular}


Table 3

Individualized characteristics of participants

\begin{tabular}{lc}
\hline & Students (n=110) \\
\hline Gender & $69 \%$ \\
Female & $31 \%$ \\
Other & $89 \%$ \\
Race & $11 \%$ \\
White & 5 point scale: 1-Less than high school diploma, \\
Minority & 2-High school diploma or GED, 3-Some \\
& college/Associates degree, 4-Bachelor's degree, \\
Mother's highest educational level & 5-Master's degree or higher \\
& 75 \\
Number & 3.44 \\
Mean & 1.17 \\
Standard deviation & 1 \\
Minimum & 5 \\
Maximum & $1-\mathrm{A}, 2-\mathrm{B}, 3-\mathrm{C}, 4-\mathrm{D}$ \\
High school grades & 75 \\
Number & 1.34 \\
Mean & .60 \\
Standard deviation & 1 \\
Minimum & 4 \\
Maximum &
\end{tabular}


Table 4

Impact of Pre-College and In-College Experiences on College Major by Arts and STEM (Regression Coefficients and t statistic)

\begin{tabular}{|c|c|c|c|c|c|c|}
\hline & \multicolumn{3}{|c|}{ STEM } & \multicolumn{3}{|c|}{ ARTS } \\
\hline & $\begin{array}{l}\text { Pre-College } \\
\text { Experiences } \\
\text { Intended } \\
\text { STEM Major }\end{array}$ & $\begin{array}{l}\text { Pre-College } \\
\text { Experiences } \\
\text { Declared } \\
\text { STEM Major }\end{array}$ & $\begin{array}{c}\text { College } \\
\text { Experiences } \\
\text { Declared } \\
\text { STEM Major }\end{array}$ & $\begin{array}{c}\text { Pre-College } \\
\text { Experiences } \\
\text { Intended } \\
\text { Arts Major }\end{array}$ & $\begin{array}{c}\text { Pre-College } \\
\text { Experiences } \\
\text { Declared } \\
\text { Art Major }\end{array}$ & $\begin{array}{c}\text { College } \\
\text { Experiences } \\
\text { Declared } \\
\text { Arts Major }\end{array}$ \\
\hline $\begin{array}{l}\text { Pre-College Independent Inquiry } \\
\text { (STEM Experience) }\end{array}$ & $\begin{array}{c}0.102 \\
(-0.63)\end{array}$ & $\begin{array}{c}0.237 \\
(-1.69)\end{array}$ & $\begin{array}{c}0.174 \\
(-0.95)\end{array}$ & $\begin{array}{c}0.048 \\
(-0.52)\end{array}$ & $\begin{array}{l}-0.102 \\
(-1.15)\end{array}$ & $\begin{array}{l}-0.007 \\
(-0.09)\end{array}$ \\
\hline $\begin{array}{l}\text { Pre-College Independent Inquiry } \\
\text { (Arts Experience) }\end{array}$ & $\begin{array}{l}-0.013 \\
(-0.11)\end{array}$ & $\begin{array}{l}-0.234 \\
(-1.88)\end{array}$ & $\begin{array}{c}-0.341^{* *} \\
(-2.75)\end{array}$ & $\begin{array}{c}0.094 \\
(-0.99)\end{array}$ & $\begin{array}{c}0.278^{* * *} \\
(-3.82)\end{array}$ & $\begin{array}{l}0.171^{*} \\
(-2.4)\end{array}$ \\
\hline $\begin{array}{l}\text { Pre-College Organized Inquiry } \\
\text { (STEM Experience) }\end{array}$ & $\begin{array}{c}0.055 \\
(-0.59)\end{array}$ & $\begin{array}{l}0.158 \\
(-1.4)\end{array}$ & $\begin{array}{c}0.135 \\
(-1.09)\end{array}$ & $\begin{array}{l}-0.144 \\
(-1.47)\end{array}$ & $\begin{array}{l}-0.116 \\
(-1.21)\end{array}$ & $\begin{array}{c}0.010 \\
(-0.12)\end{array}$ \\
\hline $\begin{array}{l}\text { Pre-College Organized Inquiry } \\
\text { (Arts Experience) }\end{array}$ & $\begin{array}{l}-0.067 \\
(-0.60)\end{array}$ & $\begin{array}{l}-0.215 \\
(-1.62)\end{array}$ & $\begin{array}{c}-0.333^{*} \\
(-2.25)\end{array}$ & $\begin{array}{l}0.518 * * * \\
(-4.72)\end{array}$ & $\begin{array}{l}0.267^{*} \\
(-2.31)\end{array}$ & $\begin{array}{l}-0.025 \\
(-0.23)\end{array}$ \\
\hline Pre-College Adult Mentoring & $\begin{array}{c}0.187 \\
(-1.06)\end{array}$ & $\begin{array}{l}0.337^{*} \\
(-2.04)\end{array}$ & $\begin{array}{c}0.271 \\
(-1.64)\end{array}$ & $\begin{array}{l}-0.082 \\
(-0.73)\end{array}$ & $\begin{array}{c}0.012 \\
(-0.14)\end{array}$ & $\begin{array}{l}0.009 \\
(-0.1)\end{array}$ \\
\hline Pre-College Peer Mentoring & $\begin{array}{l}-0.356 \\
(-1.59)\end{array}$ & $\begin{array}{l}-0.281 \\
(-0.67)\end{array}$ & $\begin{array}{l}-0.212 \\
(-0.50)\end{array}$ & $\begin{array}{l}-0.099 \\
(-0.45)\end{array}$ & $\begin{array}{l}0.259 \\
(-1.91)\end{array}$ & $\begin{array}{c}0.341 \\
(-1.47)\end{array}$ \\
\hline Female & $\begin{array}{c}0.097 \\
(-0.88)\end{array}$ & $\begin{array}{c}0.097 \\
(-0.78)\end{array}$ & $\begin{array}{c}0.140 \\
(-1.21)\end{array}$ & $\begin{array}{l}-0.202 \\
(-2.10)\end{array}$ & $\begin{array}{l}-0.189 \\
(-1.98)\end{array}$ & $\begin{array}{l}-0.124 \\
(-1.60)\end{array}$ \\
\hline $\begin{array}{l}\text { College Arts Experience } \\
\text { (Independent Inquiry) }\end{array}$ & & & $\begin{array}{l}-0.014 \\
(-0.10)\end{array}$ & & & $\begin{array}{l}0.078 \\
(-0.71)\end{array}$ \\
\hline $\begin{array}{l}\text { College STEM Experience } \\
\text { (Independent Inquiry) }\end{array}$ & & & $\begin{array}{c}0.123 \\
(-0.73)\end{array}$ & & & $\begin{array}{l}-0.079 \\
(-0.89)\end{array}$ \\
\hline $\begin{array}{l}\text { College Arts Experience } \\
\text { (Organized Inquiry) }\end{array}$ & & & $\begin{array}{c}0.222 \\
(-1.04)\end{array}$ & & & $\begin{array}{l}0.442^{* *} \\
(-3.09)\end{array}$ \\
\hline $\begin{array}{c}\text { College STEM Experience } \\
\text { (Organized Inquiry) }\end{array}$ & & & $\begin{array}{c}0.165 \\
(-1.16)\end{array}$ & & & $\begin{array}{l}-0.137 \\
(-1.29)\end{array}$ \\
\hline College Adult Mentoring & & & $\begin{array}{l}0.319^{*} \\
(-2.16)\end{array}$ & & & $\begin{array}{c}0.109 \\
(-1.52)\end{array}$ \\
\hline College Peer Mentoring & & & $\begin{array}{l}-0.370^{*} \\
(-2.11)\end{array}$ & & & $\begin{array}{l}-0.003 \\
(-0.04)\end{array}$ \\
\hline Race & $\begin{array}{l}-0.120 \\
(-0.78)\end{array}$ & $\begin{array}{l}-0.096 \\
(-0.49)\end{array}$ & $\begin{array}{l}-0.097 \\
(-0.56)\end{array}$ & $\begin{array}{l}-0.060 \\
(-0.35)\end{array}$ & $\begin{array}{l}-0.140 \\
(-0.73)\end{array}$ & $\begin{array}{l}-0.180 \\
(-0.95)\end{array}$ \\
\hline Socioeconomic Status Proxy & $\begin{array}{l}-0.051 \\
(-1.20)\end{array}$ & $\begin{array}{l}0.088 \\
-1.79\end{array}$ & $\begin{array}{c}0.083 \\
(-1.65)\end{array}$ & $\begin{array}{l}-0.047 \\
(-1.12)\end{array}$ & $\begin{array}{c}-0.068 * \\
(-2.06)\end{array}$ & $\begin{array}{c}-0.064^{*} \\
(-2.15)\end{array}$ \\
\hline High School Grades & $\begin{array}{c}0.033 \\
(-0.39)\end{array}$ & $\begin{array}{c}0.052 \\
(-0.48)\end{array}$ & $\begin{array}{c}0.047 \\
(-0.49)\end{array}$ & $\begin{array}{l}-0.166 \\
(-1.96)\end{array}$ & $\begin{array}{l}-0.106 \\
(-1.04)\end{array}$ & $\begin{array}{l}-0.088 \\
(-0.96)\end{array}$ \\
\hline Incercept & $\begin{array}{l}1.094^{* *} \\
(-3.42)\end{array}$ & $\begin{array}{c}0.216 \\
(-0.43)\end{array}$ & $\begin{array}{c}0.314 \\
(-0.57)\end{array}$ & $\begin{array}{c}0.775 \\
(-1.95)\end{array}$ & $\begin{array}{c}0.416 \\
(-1.20)\end{array}$ & $\begin{array}{c}0.182 \\
(-0.46)\end{array}$ \\
\hline $\mathrm{N}$ & 75 & 75 & 75 & 75 & 75 & 75 \\
\hline
\end{tabular}

$\mathrm{t}$ statistics in parentheses

${ }^{*} \mathrm{p}<0.05,{ }^{* *} \mathrm{p}<0.01,{ }^{* * *} \mathrm{p}<0.001$ 
Table 5

Descriptive Statistics and t-test Results for Experiences before and during college and impact on college major selection

\begin{tabular}{|c|c|c|c|c|c|c|c|c|c|}
\hline \multirow[b]{2}{*}{ Outcome } & \multicolumn{2}{|c|}{$\begin{array}{l}\text { Before College } \\
\text { Experiences }\end{array}$} & \multicolumn{2}{|c|}{$\begin{array}{c}\text { During College } \\
\text { Experiences }\end{array}$} & \multirow[b]{2}{*}{$\mathrm{n}$} & \multirow{2}{*}{$\begin{array}{l}95 \% \text { CI for } \\
\text { Mean } \\
\text { Difference }\end{array}$} & \multirow[b]{2}{*}{$\mathrm{t}$} & & \multirow[b]{2}{*}{$\mathrm{df}$} \\
\hline & $\mathrm{M}$ & SD & $\mathrm{M}$ & SD & & & & & \\
\hline Independent Inquiry & 3.253 & 1.263 & 3.162 & 1.323 & 99 & $-0.167,0.349$ & 0.699 & & 98 \\
\hline Organized Inquiry & 2.622 & 1.197 & 2.867 & 1.359 & 98 & $-0.500,0.011$ & -1.899 & $*$ & 97 \\
\hline Peer Mentoring & 2.653 & 1.219 & 3.010 & 1.335 & 98 & $-0.624,-0.090$ & -2.651 & $*$ & 97 \\
\hline Adult Mentoring & 3.020 & 1.292 & 3.316 & 1.476 & 98 & $-0.581,-0.010$ & -2.059 & $*$ & 97 \\
\hline
\end{tabular}

${ }^{*} \mathrm{p}<.05$.

Table 6

Perception of Impact - Comparing Pre-College and College Experience Types on College Major Selection (Regression Coefficients and t statistics)

\begin{tabular}{|c|c|c|c|c|c|c|c|c|c|c|c|c|}
\hline & \multicolumn{3}{|c|}{ Controlled } & \multicolumn{3}{|c|}{ Controlled } & \multicolumn{3}{|c|}{ Controlled } & \multicolumn{3}{|c|}{ Controlled } \\
\hline & $\begin{array}{c}\text { No } \\
\text { Controls }\end{array}$ & $\begin{array}{c}\text { For } \\
\text { Female } \\
\text { Only }\end{array}$ & $\begin{array}{c}\text { All } \\
\text { Controls }\end{array}$ & $\begin{array}{c}\text { No } \\
\text { Controls }\end{array}$ & $\begin{array}{c}\text { For } \\
\text { Female } \\
\text { Only }\end{array}$ & $\begin{array}{c}\text { All } \\
\text { Controls }\end{array}$ & $\begin{array}{c}\text { No } \\
\text { Controls }\end{array}$ & $\begin{array}{c}\text { For } \\
\text { Female } \\
\text { Only }\end{array}$ & $\begin{array}{c}\text { All } \\
\text { Controls }\end{array}$ & $\begin{array}{c}\text { No } \\
\text { Controls }\end{array}$ & $\begin{array}{c}\text { For } \\
\text { Female } \\
\text { Only }\end{array}$ & $\begin{array}{c}\text { All } \\
\text { Controls }\end{array}$ \\
\hline & \multicolumn{3}{|c|}{ Pre-College Intended Arts Major } & \multicolumn{3}{|c|}{$\begin{array}{l}\text { Pre-College Intended STEM } \\
\text { Major }\end{array}$} & \multicolumn{3}{|c|}{ College Declared Arts Major } & \multicolumn{3}{|c|}{ College Declared STEM Major } \\
\hline Pre-College Individual Inquiry & $\begin{array}{l}0.056 \\
(1.62)\end{array}$ & $\begin{array}{l}0.027 \\
(0.65)\end{array}$ & $\begin{array}{l}0.043 \\
(0.95)\end{array}$ & $\begin{array}{l}0.007 \\
(0.18)\end{array}$ & $\begin{array}{l}-0.011 \\
(-0.22)\end{array}$ & $\begin{array}{l}-0.016 \\
(-0.31)\end{array}$ & $\begin{array}{l}0.024 \\
(0.65)\end{array}$ & $\begin{array}{l}-0.013 \\
(-0.32)\end{array}$ & $\begin{array}{l}-0.008 \\
(-0.20)\end{array}$ & $\begin{array}{l}-0.023 \\
(-0.43)\end{array}$ & $\begin{array}{l}-0.027 \\
(-0.38)\end{array}$ & $\begin{array}{l}-0.020 \\
(-0.26)\end{array}$ \\
\hline Pre-College Organized Inquiry & $\begin{array}{l}0.045 \\
(1.09)\end{array}$ & $\begin{array}{l}0.046 \\
(0.75)\end{array}$ & $\begin{array}{l}0.012 \\
(0.18)\end{array}$ & $\begin{array}{l}0.010 \\
(0.22)\end{array}$ & $\begin{array}{l}-0.022 \\
(-0.44)\end{array}$ & $\begin{array}{l}-0.005 \\
(-0.10)\end{array}$ & $\begin{array}{l}0.037 \\
(0.92)\end{array}$ & $\begin{array}{l}0.068 \\
(1.86)\end{array}$ & $\begin{array}{l}0.059 \\
(1.45)\end{array}$ & $\begin{array}{l}0.030 \\
(0.54)\end{array}$ & $\begin{array}{l}0.045 \\
(0.67)\end{array}$ & $\begin{array}{l}0.045 \\
(0.63)\end{array}$ \\
\hline Pre-College Adult Mentoring & $\begin{array}{l}0.048 \\
(1.43)\end{array}$ & $\begin{array}{l}0.044 \\
(1.16)\end{array}$ & $\begin{array}{l}0.052 \\
(1.29)\end{array}$ & $\begin{array}{l}0.027 \\
(0.71)\end{array}$ & $\begin{array}{l}-0.048 \\
(-1.25)\end{array}$ & $\begin{array}{l}-0.057 \\
(-1.32)\end{array}$ & $\begin{array}{l}0.037 \\
(1.10)\end{array}$ & $\begin{array}{l}0.031 \\
(0.91)\end{array}$ & $\begin{array}{l}0.028 \\
(0.72)\end{array}$ & $\begin{array}{l}0.015 \\
(0.32)\end{array}$ & $\begin{array}{l}-0.036 \\
(-0.56)\end{array}$ & $\begin{array}{l}-0.032 \\
(-0.44)\end{array}$ \\
\hline Pre-College Peer Mentoring & $\begin{array}{l}-0.096^{*} \\
(-2.56)\end{array}$ & $\begin{array}{l}-0.083 \\
(-1.66)\end{array}$ & $\begin{array}{l}-0.084 \\
(-1.56)\end{array}$ & $\begin{array}{l}0.004 \\
(0.09)\end{array}$ & $\begin{array}{l}0.054 \\
(1.20)\end{array}$ & $\begin{array}{l}0.060 \\
(1.23)\end{array}$ & $\begin{array}{c}-0.104^{* *} \\
(-2.80)\end{array}$ & $\begin{array}{c}-0.118^{* *} \\
(-2.83)\end{array}$ & $\begin{array}{c}-0.108^{*} \\
(-2.20)\end{array}$ & $\begin{array}{l}-0.004 \\
(-0.07)\end{array}$ & $\begin{array}{l}-0.032 \\
(-0.52)\end{array}$ & $\begin{array}{l}-0.048 \\
(-0.62)\end{array}$ \\
\hline Female & & $\begin{array}{l}-0.205 \\
(-1.83)\end{array}$ & $\begin{array}{l}-0.191 \\
(-1.54)\end{array}$ & & $\begin{array}{l}0.070 \\
(0.65)\end{array}$ & $\begin{array}{l}0.069 \\
(0.53)\end{array}$ & & $\begin{array}{l}-0.182 \\
(-1.76)\end{array}$ & $\begin{array}{l}-0.115 \\
(-1.08)\end{array}$ & & $\begin{array}{l}0.163 \\
(1.22)\end{array}$ & $\begin{array}{l}0.073 \\
(0.46)\end{array}$ \\
\hline College Individual Inquiry & & & & & & & $\begin{array}{l}0.003 \\
(0.09)\end{array}$ & $\begin{array}{l}0.008 \\
(0.20)\end{array}$ & $\begin{array}{l}0.034 \\
(1.00)\end{array}$ & $\begin{array}{l}0.062 \\
(1.18)\end{array}$ & $\begin{array}{l}0.084 \\
(1.28)\end{array}$ & $\begin{array}{l}0.079 \\
(1.14)\end{array}$ \\
\hline College Organized Inquiry & & & & & & & $\begin{array}{l}0.015 \\
(0.40)\end{array}$ & $\begin{array}{l}0.017 \\
(0.47)\end{array}$ & $\begin{array}{l}0.000 \\
(0.01)\end{array}$ & $\begin{array}{l}-0.008 \\
(-0.15)\end{array}$ & $\begin{array}{l}-0.032 \\
(-0.56)\end{array}$ & $\begin{array}{l}-0.042 \\
(-0.64)\end{array}$ \\
\hline College Adult Mentoring & & & & & & & $\begin{array}{l}-0.049 \\
(-1.41)\end{array}$ & $\begin{array}{l}-0.061 \\
(-1.53)\end{array}$ & $\begin{array}{l}-0.054 \\
(-1.28)\end{array}$ & $\begin{array}{l}0.018 \\
(0.37)\end{array}$ & $\begin{array}{l}0.015 \\
(0.24)\end{array}$ & $\begin{array}{l}0.020 \\
(0.27)\end{array}$ \\
\hline College Peer Mentoring & & & & & & & $\begin{array}{l}0.045 \\
(1.13)\end{array}$ & $\begin{array}{l}0.080 \\
(1.93)\end{array}$ & $\begin{array}{l}0.053 \\
(1.13)\end{array}$ & $\begin{array}{l}0.044 \\
(0.79)\end{array}$ & $\begin{array}{l}0.018 \\
(0.28)\end{array}$ & $\begin{array}{l}0.043 \\
(0.51)\end{array}$ \\
\hline Race & & & $\begin{array}{l}-0.200 \\
(-1.19)\end{array}$ & & & $\begin{array}{l}-0.106 \\
(-0.75)\end{array}$ & & & $\begin{array}{l}-0.185 \\
(-1.25)\end{array}$ & & & $\begin{array}{l}-0.070 \\
(-0.30)\end{array}$ \\
\hline Socioeconomic Status Proxy & & & $\begin{array}{l}0.018 \\
(0.42)\end{array}$ & & & $\begin{array}{l}-0.055 \\
(-1.53)\end{array}$ & & & $\begin{array}{l}-0.012 \\
(-0.38)\end{array}$ & & & $\begin{array}{l}0.059 \\
(1.10)\end{array}$ \\
\hline High School Grades & & & $\begin{array}{l}-0.082 \\
(-0.92)\end{array}$ & & & $\begin{array}{l}-0.007 \\
(-0.09)\end{array}$ & & & $\begin{array}{l}-0.043 \\
(-0.54)\end{array}$ & & & $\begin{array}{l}-0.016 \\
(-0.15)\end{array}$ \\
\hline Intercept & $\begin{array}{l}0.031 \\
(0.21)\end{array}$ & $\begin{array}{l}0.234 \\
(1.07)\end{array}$ & $\begin{array}{l}0.575 \\
(1.51)\end{array}$ & $\begin{array}{c}0.600^{* * * *} \\
(3.69)\end{array}$ & $\begin{array}{c}0.855^{* * *} \\
(3.43)\end{array}$ & $\begin{array}{c}1.169^{* * * *} \\
(4.60)\end{array}$ & $\begin{array}{l}0.112 \\
(0.80)\end{array}$ & $\begin{array}{l}0.244 \\
(1.22)\end{array}$ & $\begin{array}{l}0.191 \\
(0.76)\end{array}$ & $\begin{array}{l}0.177 \\
(0.91)\end{array}$ & $\begin{array}{l}0.376 \\
(1.34)\end{array}$ & $\begin{array}{l}0.524 \\
(1.28)\end{array}$ \\
\hline $\mathrm{N}$ & 100 & 75 & 75 & 100 & 75 & 75 & 98 & 75 & 75 & 98 & 75 & 75 \\
\hline
\end{tabular}


Appendix A: Dependent Variable Scales

Independent Inquiry (Reliability = .62 (before-college-experience), 0.75 (during-collegeexperience)). Experiences: (a) Tinkered with mechanical devices (e.g. bicycle, sewing machine, rifle, bow and arrow, car jack, pulleys, wheelbarrow), (b) Tinkered with electrical devices (e.g. cars, batteries, and bulbs, radio, TV, computer), (c) Mixed chemical/materials, Engage with chemistry sets, kitchen chemistry, (d) Took care of or trained an animal, (e) Planted seeds, watched plants grow, watched animal behavior, collected things in nature, (f) Observed or studied stars and other astronomical objects, (g) Watched aircraft or visited airfield, (h) Read science or technology blogs, books or magazines, (i) Read art or music blogs, books or magazines, (j) Learned a musical instrument on my own.

Organized Inquiry (Reliability = .74 (before-college-experience), 0.84 (during-collegeexperience)). Experiences: (a) Participated in science, technology, engineering or math clubs, camps, or competitions, (b) Participated in fine arts and/or performing art ensembles, clubs, camps or competitions, (c) Interned and/or worked at a job that inspired me to learn more, (d) Took private fine arts and /or performing arts lessons, (e) Had a tutor or private lessons in science, technology, engineering, or math, (f) Took a class that inspired me to learn more, (g) Completed a culminating academic experience (capstone course, project or thesis, comprehensive exam, portfolio, etc.), (h) Participated in academic clubs or programs for women and/or minority students, (i) Participated in non-academic clubs or programs for women and/or minority students.

Adult Mentoring (Reliability $=.56$ (before-college-experience), 0.69 (during-collegeexperience)). Experiences: (a) An adult (non-parent/guardian), teacher, or faculty member introduced me to a discipline that I did not know existed before, (b) An adult (nonparent/guardian), teacher, or faculty member praised my work in topics or activities in science, technology, mathematics, or the arts, (c) An adult (non-parent/guardian), teacher, or faculty member helped me find opportunities to engage with science, technology, mathematics, or the arts.

Peer Mentoring (Reliability = .64 (before-college-experience), 0.85 (during-collegeexperience)). Experiences: (a) Worked with friends or classmates on activities or assignments related to math or science, (b) Participated in a play, music ensemble, or art project with friends, (c) Encouraged friends to explore new subject areas, (d) Encouraged friends to join groups, clubs or teams, (e) encouraged by sibling to select your major or career path.

Design Process (Reliability $=.85$ (before-college-experience), 0.86 (during-collegeexperience)). Experiences: (a) Was inspired to seek insight into and/or understanding of a design problem or artistic competition, (b) Defined or conceptualized a meaningful creation, (c) Innovated with different ideas to create an artistic design or solve a problem, (d) Improved my 
work/production through practice and iteration, (e) Evaluated my work/production through test or rehearsal, (f) Presented my work/production to an audience. 